\title{
On the features of crystallization methods used for the purification of aqueous solutions of cesium iodide
}

\author{
V.L.Cherginets, T.V.Ponomarenko, T.P.Rebrova, \\ A.G.Varich, A.L.Rebrov, Yu.N.Datsko \\ Institute for Scintillation Materials, STC "Institute for Single Crystals", \\ National Academy of Sciences of Ukraine, \\ 60 Nauky Ave., 61072 Kharkiv, Ukraine
}

Received March 20, 2018

\begin{abstract}
Comparative analysis of Csl purification methods: mass crystallization with natural cooling (MC), low-temperature directed crystallization without stirring (LTDC/ws) and low-temperature mixed crystallization (LTMC) is presented. The MC routine possesses the highest cooling rate $\left(6-10^{\circ} \mathrm{C} / \mathrm{h}\right)$ and the smallest effective purification coefficients $(\beta=$ $0.07 \div 0.2$ ) from $\mathrm{Na}, \mathrm{K}$ and $\mathrm{Rb}$, however the yield of the product per stage is only $60 \%$. The low-temperature methods are characterized by low cooling rate of $\sim 1^{\circ} \mathrm{C} / \mathrm{h}$ and higher yields of the purified product per stage (95-97\%) and $\beta$ values closer to 1 than those for MC; the purification occurs especially hardly in the case of LTDC/ws $(\beta \sim 0.9)$. The mentioned crystallization methods do not provide the removal of $\mathrm{TI}$ which is accumulated in the product. With respect to efficiency of the purification 1 stage of $\mathrm{MC}$ is equivalent to 3-4 stages of LTMC or 10-11 stages of LTDC/ws and the yield of the product (CsI) is $60 \%, 85-90 \%$ and 55-70\%, respectively. The LTMC method seems the most promising for the obtaining of extra pure Csl of enhanced quality due to low enough values of $\beta$ for $\mathrm{Na}, \mathrm{K}$ and $\mathrm{Rb}(\beta=0.46 \div 0.6)$ and considerably smaller than in the case of $\mathrm{MC}$ rate of cooling (a degree of overcooling).
\end{abstract}

Keywords: cesium iodide, mass crystallization, low-temperature, crystallization, admixture distribution.

Проведен сравнительный анализ методов очистки йодида цезия: массовой кристаллизации с естественным охлаждением (МК), низкотемпературной направленной кристаллизации без перемешивания (НHК/бп) и низкотемпературной смешанной кристаллизации (НМК). Метод МК характеризуется наибольшей скоростью охлаждения (6$10^{\circ} \mathrm{C} /$ ч) и наименьшими значениями әффективного коэффициента очистки $(\beta=$ $0.07 \div 0.2)$ от $\mathrm{Na}, \mathrm{K}$ и $\mathrm{Rb}$, при этом выход продукта за 1 стадию очистки составляет $60 \%$. Низкотемпературным методам свойственна низкая скорость охлаждения $\left(\sim 1^{\circ} \mathrm{C} / ч\right)$ и более высокий выход очищенного продукта за 1 стадию (95-97\%), но значения $\beta$ ближе к 1 , чем в случае МК, особенно тяжело проходит очистка в случае ННК/бп ( $\beta$ 0.9). Рассмотренные кристаллизационные методы не обеспечивают удаления TI, который накапливается в продукте. В отношении әффективности очистки 1 стадия МК эквивалентна 3-4 стадиям НМК или 10-11 стадиям НHК/бп, при этом выход продукта (Csl) составляет $60 \%$, 85-90\% и 55-70\%, соответственно. Метод НМК является наиболее перспективным для получения особо чистого Csl повышенного качества вследствие достаточно низких значений $\beta$ для $\mathrm{Na}, \mathrm{K}$ и $\mathrm{Rb}(\beta=0.46 \div 0.6)$ и значительно более низкой по сравнению с МК скорости охлаждения (степень переохлаждения). 
Особливості кристалізаційних методів очистки водних розчинів йодиду цезію. В.Л.Чергинець, Т.В.Поноларенко, Т.П.Реброва, А.Г.Варич, О.Л.Ребров, Ю.М.Дацько.

Проведено порівняльний аналіз методів очистки йодиду цезію: масової кристалізації з природним охолодженням (МК), низькотемпературної спрямованої кристалізації без перемішування (НСК/бп) і низькотемпературної мішаної кристалізації (НМК). Метод МК характеризується найбільшою швидкістю охолодження $\left(6-10^{\circ} \mathrm{C} /\right.$ год) і найменшими значеннями ефективного коефіцієнту очистки $(\beta=0.07 \div 0.2)$ від $\mathrm{Na}, \mathrm{K}$ i $\mathrm{Rb}$, при цьому вихід продукту за 1 стадію очистки складає $60 \%$. Низькотемпературним методам притаманна низька швидкість охолодження $\left(\sim 1^{\circ} \mathrm{C} /\right.$ год) і вищий вихід очищеного продукту за 1 стадію (95-97\%), але значення $\beta$ є ближчими до 1 , ніж у випадку MК, особливо важко відбувається очистка при використанні НСК/бп ( $\beta \sim 0.9)$. Розглянуті кристалізаційні методи не забезпечують видалення TI, який накопичується у продукті. У відношенні ефективності очистки 1 стадія МК є еквівалентною 3-4 стадіям HМК або 10-11 стадіям НCK/бп, при цьому вихід продукту (Csl) складає 60 \%, 85$90 \%$ і 55-70\%, відповідно. Метод НМК є найбільш перспективним для одержання особливо чистого Csl підвищеної якості з огляду на достатньо низькі значення $\beta$ для $\mathrm{Na}, \mathrm{K}$ i Rb $(\beta=0.46 \div 0.6)$ і значно нижчу, ніж у випадку $\mathrm{MK}$, швидкість охолодження (міру переохолодження).

\section{Introduction}

The production of extra pure Csl or purification of this salt obtained from crystal growth wastes is one of the most important tasks for organizations which activity concerns the growth of optical single crystals. It is generally accepted that the purification process consists of the filtering of CsI aqueous solution via active carbon, the preliminary chemical purification of the solution leading to the removal of non-isomorphic admixtures and the final deep purification which is provided by several crystallization methods.

The filtering makes it possible to remove organic admixtures and, partially, thallium iodide if the solution was obtained from the wastes of CsI:Tl single crystals. The first stage of the chemical purification is the treatment of the filtered solution by $\mathrm{Ba}(\mathrm{OH})_{2}$ that permits to remove sulfates and admixtures of heavy metals, magnesium, aluminum. Then the solution is treated by $\mathrm{Cs}_{2} \mathrm{CO}_{3}$ that results in the removal of alkaline earth metal admixtures which are precipitated as the corresponding carbonates. However, the solution purified by such a manner contains isomorphic admixtures ( $\mathrm{Na}, \mathrm{K}, \mathrm{Rb}, \mathrm{Tl}$ ) which cannot be successfully removed by the usual chemical methods.

So, the crystallization methods must be used for the final purification of CsI solution. These methods are usual mass crystallization (MC), low-temperature directed crystallization (LTDC) and low-temperature mixed crystallization (LTMC). Each of these crystallization methods has both obvious advantages and proper to it lacks or difficulties. The comparative analysis of features of the mentioned crystallization methods is presented below.

\section{Experimental}

The mass crystallization was conducted using the solution of Csl wastes after the stage of chemical treatment.The solution was evaporated in the sealed titanium apparatus under the conditions of lowered pressure $(0.1 \mathrm{~atm})$ and the temperature of $75-$ $80^{\circ} \mathrm{C}$ until the formation of suspended Csl particles. Then the solution was drained in the crucible and cooled to room temperature $\left(r t, 18-25^{\circ} \mathrm{C}\right)$ during $6-10 \mathrm{~h}$. The precipitated crystals were separated from the mother waters. For the following crystallization stages $100 \mathrm{~kg}$ of the obtained Csl was mixed with $120 \mathrm{~kg}$ of water and the mixture was heated for the homogenization and cooled to $r$.

Low-temperature directed crystallization was performed using the mother water of the $1^{\text {st }}$ mass crystallization which was diluted to make the concentration of Csl equal to 27.5 wt.\%. For low-temperature mixed crystallization the solution containing 38 wt. \% of Csl was used. Both low-temperature crystallization processes were performed in the freezing chamber 'BEKO HSA $40520^{\prime}$ cooled to $-14-18^{\circ} \mathrm{C}$. 1.5 l PET bottles were used as containers. The crystallization degree was $0.96-0.97$ and the time required for the finishing of the purification process was ca. $36 \mathrm{~h}$. After each stage ca. $50 \mathrm{ml}$ of residual liquid was removed and the frozen WSE was heated to the formation of homogeneous solution which was subjected to the next stage of low-temperature crystallization. 
The analysis of admixture content was performed as it was described in [1].

\section{Results and discussion}

To facilitate the comparative analysis of the crystallization methods we built the phase diagram of $\mathrm{Csl}-\mathrm{H}_{2} \mathrm{O}$ system (Fig. 1) according to the data of [1]. Recently we performed the examination of the said methods and some results that gives us possibility to make more clear imagination about the features of these crystallization processes are presented below.

For the quantitative characterization of the efficiency of the purification processes we used the definition of the separation element $(S E)$. The action of $S E$ is described by the following scheme:

$$
P_{(i-1)}\left(x_{(i-1)}\right) \rightarrow\left(S E_{i}\right) \rightarrow P_{i}\left(x_{i}\right),
$$

where $P_{(i-1)}$ the product from the stage of purification ' $i-1$ ' with the concentration of admixture $x_{(i-1)}$ entering $S E$ number ' $i$ ' $\left(S E_{i}\right)$ in a series of separation elements, $P_{i}$ the product of purification exiting from $S E_{i}$ and concentration of admixture in this product is $x_{(i-1)}$.

The efficiency of $S E$ can be described by the effective purification coefficient $\beta$ :

$$
\beta=x_{i} / x_{(i-1)},
$$

and for the processes leading to the removal of the admixture $\beta<1$. To facilitate the perception of the information (unite data in one figure) we use $-\log \beta$ values.

\section{Mass crystallization ( $M C$ )}

This way is used to produce cesium iodide in relatively large amounts (up to $500 \mathrm{~kg}$ per a month). The essence of the mass crystallization of Csl can be understood from Fig. 1 (arrow MC). The solution after the chemical purification is heated up to $80-85^{\circ} \mathrm{C}$ and evaporated up to the forma-

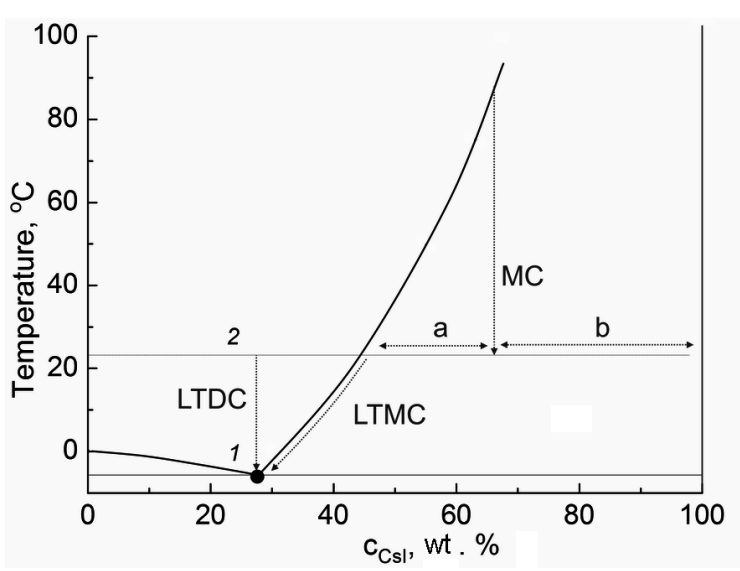

Fig. 1. The phase diagram of $\mathrm{Csl}-\mathrm{H}_{2} \mathrm{O}$ system: 1 - water-salt eutectic, WSE $(t=-$ $\left.5.6^{\circ} \mathrm{C}, c_{\mathrm{Csl}}=27.5 \mathrm{wt} . \%\right), 2-$ the line corresponding to room temperature, MC, LTDC and LTMC - the lines corresponding to mass crystallization (MC), low-temperature directed crystallization (LTDC) and low-temperature mixed crystallization (LTMC), respectively.

tion of the saturated solution. Then the saturated solution is cooled down to $r t$ by the natural cooling (horizontal line 2 in Fig. $1)$, so, the average rate of cooling is ca. $6-10^{\circ} \mathrm{C} / \mathrm{h}$. The yield of the product after the operation can be calculated using sections ' $a$ ' and ' $b$ ' (Fig. 1) which are the parts of the connode. As is known the mass ratio of mother water (42-43\% solution of Csl) to the crystallized salt is $b: a$ ratio which is equal to 1.73 from Fig. 1, i.e., the ratio of the amounts of Csl in the solution and in the solid phase are (1.73.0.42) to 1 . In other words 42 per cent of Csl remain in the solution and the yield of the purified salt after each crystallization does not exceed 60 per cent. It is obvious that after $n$ crystallizations the direct product yield $N_{\mathrm{Csl}}$ (without the use of mother waters) is estimated by such a manner:

$$
N_{\text {Csl }} \leq 0.6^{n}
$$

Table 1. Concentrations of isomorphic admixtures $\mathrm{Na}\left(c_{\mathrm{Na}}\right), \mathrm{K}\left(c_{\mathrm{K}}\right), \mathrm{Rb}\left(c_{\mathrm{Rb}}\right)$ and $\mathrm{TI}\left(c_{\mathrm{Tl}}\right)$ in initial

Csl solution and salts obtained by industrial mass crystallization

\begin{tabular}{|c|c|c|c|c||}
\hline \hline Sample origin & $c_{\mathrm{Na}}$ & $c_{\mathrm{K}}$ & $c_{\mathrm{Rb}}$ & $c_{\mathrm{Tl}}$ \\
\hline Solution after chemical treatment & 1.9 & $6.5 \cdot 10^{-3}$ & $2.4 \cdot 10^{-4}$ & $3.0 \cdot 10^{-4}$ \\
Product of $1^{\text {st }}$ crystallization & $7.6 \cdot 10^{-2}$ & $4.8 \cdot 10^{-4}$ & $5 \cdot 10^{-5}$ & $3.0 \cdot 10^{-4}$ \\
Product of $2^{\text {nd }}$ crystallization & $6.0 \cdot 10^{-3}$ & $5 \cdot 10^{-5}$ & $<5 \cdot 10^{-5}$ & $7.5 \cdot 10^{-4}$ \\
Product of $3^{\text {rd }}$ crystallization & $7.1 \cdot 10^{-4}$ & $2 \cdot 10^{-5}$ & $<5 \cdot 10^{-5}$ & $1.0 \cdot 10^{-3}$ \\
\hline
\end{tabular}


i.e., 36 per cent after the $2^{\text {nd }}$ crystallization and $c a .22$ per cent after $3^{\text {rd }}$ one (usually just 3 crystallizations are used).

So, the yield of the solid Csl after multiply mass crystallizations is not high. However,it is interesting to analyze the data concerning the efficiency of the purification from isomorphic admixtures presented in Table 1.

The dependence of $-\log \beta$ against a number of mass crystallization stages is presented in Fig. 2.

As is seen, the isomorphic admixtures can be divided into two groups with respect to the sign of $-\log \beta$ : for $\mathrm{T} \mid-\log \beta$ value is negative, whereas for $\mathrm{Na}, \mathrm{K}, \mathrm{Rb}$ the values of $-\log \beta$ are essentially positive (there is only one point for $\mathrm{Rb}$ in Fig. 2 since after the $1^{\text {st }}$ crystallization its concentration becomes lower than the detection limit). It means that the alkaline metal admixtures are effectively removed from Csl during the mass crystallization; however, thallium is accumulated in the product of the purification. These results agree qualitatively with the data of [2] obtained for LTMC. Besides, we can see an obvious trend of $-\log \beta$ approaching to 0 for $\mathrm{Na}$ and $\mathrm{K}$. This can be explained by the known fact that the approaching of distribution coefficient of admixtures to 1 takes place in the case if a number of defects in the crystallized phase is comparable with the concentrations of captured admixtures [3]. When concentration of an impurity essentially exceeds the number of the defects the distribution coefficient (and, hence, $\beta$ ) should be practically constant.

Concerning the behavior of $\mathrm{Tl}$ admixture it should be noted that for this admixture the change of $\beta$ going from initial solution to product of the $3^{\text {rd }}$ crystallization is not pronounced (the slope is statistical zero) since $\beta$ is close to 1 .

Finishing the discussion about the mass crystallization of CsI from the aqueous solution, it is necessary to give the average values of $-\log \beta$ for the studied isomorphic admixtures with the standard deviations: $1.14 \pm 0.23(\mathrm{Na}), 0.83 \pm 0.40 \quad(\mathrm{~K}), 0.68 \quad(\mathrm{Rb}$, single result), $-0.17 \pm 0.2$ (Tl). These values correspond to the following values of $\beta$ : $0.07(\mathrm{Na}), 0.15(\mathrm{~K}), 0.21(\mathrm{Rb})$ and $1.48(\mathrm{Tl})$.

2. Low-temperature directed crystallization ( $L T D C)$

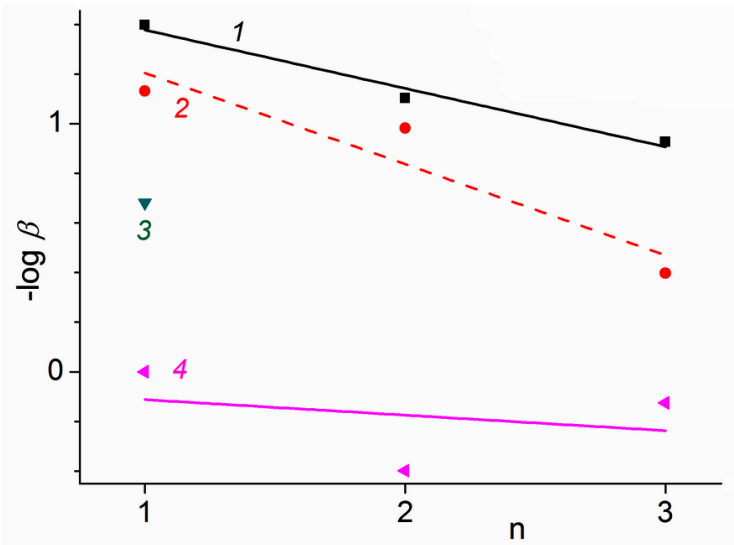

Fig. 2. The dependences of negative logarithm of effective purification coefficient $\beta(-\log \beta)$ of Csl from the isomorphic admixtures against the number of the mass crystallizations stages (n): $1-\mathrm{Na}, 2-\mathrm{K}, 3-\mathrm{Rb}, 4-\mathrm{Tl}$.

The essence of this process is described in details in monographs $[4,5]$. Nevertheless the principal features of this process should be mentioned here. Csl concentration in the solution to be crystallized is $27.5 \mathrm{wt}$. $\%$ (water-salt eutectic, WSE), optimal temperature is $-13^{\circ} \mathrm{C}$ (according to [4]), the rate of rotation of an ampoule with solution (stirring) is $c a .600 \mathrm{rpm}$. The crystallization finishes after the solidification of 90-95\% of the solution. The method efficiency was tested on the samples of small volume $c a .100 \mathrm{ml}$ [4].

The course of LTDC corresponds to 'LTDC' arrow in Fig. 1. The cooling of the solution corresponding to the WSE composition to temperatures lower than $-5.6^{\circ} \mathrm{C}$ results in simultaneous crystallization of Csl and water (ice) and the total composition of the solid fraction corresponds to the composition of the liquid (27.5 wt.\% of CsI and 72.5 wt. $\%$ of ice).

Returning to the use of LTDC for large amount of solutions it should be noted that the main difficulty with the application of the developed method at industrial scale consists in the stirring. The application of $600 \mathrm{rpm}$ stirring/rotation to the vessels of the volume of 11 and above is doubted, besides, the use of stirring will lead to considerable complication of both the equipment and the technology. Therefore, the routine of LTDC without stirring (LTDC/ws) deserves to be considered and its efficiency should be checked.

The essence of the experiment consisted in the freezing of Csl solution with the concentration corresponding to the WSE com- 
Table 2. Concentrations of isomorphic admixtures $\mathrm{Na}\left(c_{\mathrm{Na})}, \mathrm{K}\left(c_{\mathrm{K}}\right)\right.$ and $\mathrm{Rb}\left(c_{\mathrm{Rb}}\right)$ in initial Csl solution obtained from mother water of $1^{\text {st }} \mathrm{MC}$ and salts obtained by LTDC/ws of WSE Csl- $\mathrm{H}_{2} \mathrm{O}$, freezing chamber temperature was $-14--19^{\circ} \mathrm{C}$, volume of vessel (bottle) was 21

\begin{tabular}{|c|c|c|c||}
\hline \hline$n$ & $c_{\mathrm{Na}}$ & $c_{\mathrm{K}}$ & $c_{\mathrm{Rb}}$ \\
\hline 0 & 3.10 & $3.3 \cdot 10^{-2}$ & $7.7 \cdot 10^{-4}$ \\
1 & 2.70 & $3.0 \cdot 10^{-2}$ & $7.1 \cdot 10^{-4}$ \\
3 & 2.30 & $2.5 \cdot 10^{-2}$ & $5.7 \cdot 10^{-4}$ \\
5 & 2.10 & $2.1 \cdot 10^{-2}$ & $4.7 \cdot 10^{-4}$ \\
\hline
\end{tabular}

position. The time required for the solidification of 96-97\% of the solution was 20$24 \mathrm{~h}$ and the average rate of cooling was ca. $1^{\circ} \mathrm{C} / \mathrm{h}$. WSE Csl- $\mathrm{H}_{2} \mathrm{O}$ was prepared from the mother water from the $1^{\text {st }}$ mass crystallization to check the possibility of its purification by LTDC/ws. The concentration of $\mathrm{Tl}$ in this solution was lower than the detection limit since $\mathrm{TI}$ had been quantitatively removed from the mother solution by the crystallized cesium iodide.

The analysis was not performed for each LTDC/ws stage. The reason consisted in the fact that the concentration of an admixture in the product is decreased by a factor of $1 / \beta^{n}$ after $n$ crystallizations, i.e.:

$$
x_{n}=x_{0} \cdot \beta^{n},
$$

or, in logarithmic form

$$
\log x_{n}=\log x_{0}+n \log \beta .
$$

The latter equation means that the dependence of $\log x_{i}$ vs. $n$ should be linear and the slope is equal to $\log \beta$.

The concentrations of the isomorphic admixtures in Csl after $n$ stages of LTDC/ws are collected in Table 2 and the dependence of negative logarithm of isomorphic admixtures' concentration vs. a number of LTDC/ws stages is presented in Fig. 2. All the plots are practically linear that gives the evidence of the stability of $\beta$ for all the stages caused by both slow cooling and relatively high concentration of the isomorphic impurities. The plots can be described by the slopes of 0.044 for $\mathrm{Na}(\beta=0.90), 0.053$ for $\mathrm{K}(\beta=0.88)$ and 0.059 for $\mathrm{Rb}(\beta=$ 0.87 ).

The data presented in Table 2 show that the performing of 10 stages of LTDC/ws leads to the decrease of $\mathrm{Na}$ concentration by a factor of 3 ; $\mathrm{K}$ and $\mathrm{Rb}$ concentration de-

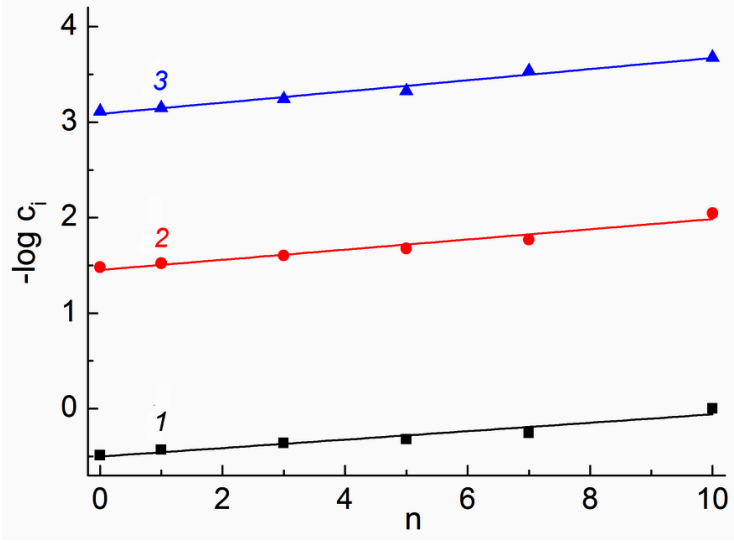

Fig. 3. The dependences of $-\log c_{i}$ (wt. \%) from a number of stages of LTDC without stirring at freezing chamber temperature was $-14--19^{\circ} \mathrm{C}$ for admixtures of $\mathrm{Na}(1, i=$ $\mathrm{Na}), \mathrm{K}(2, i=\mathrm{K})$ and $\mathrm{Rb}(3, i=\mathrm{Rb})$.

crease by a factor of 3.7 . The calculation of product yield can be performed using the following equation: $N_{\mathrm{Csl}} \leq 0.96^{n}$, that gives the yield after 10 stages LTDC/ws equal to $66 \%$.

So, the efficiency of LTDC/ws method for the purification of WSE Csl- $\mathrm{H}_{2} \mathrm{O}$ is low and it cannot have practical application in such a simple form.

\section{Low-temperature mixed crystallization (LTMC)}

LTMC is the routine proposed recently concerning existing practical conditions in Csl wastes purification. The mass crystallization process leads to the obtaining of two resulting products: crystallized cesium iodide with lowered concentration of a majority of admixtures and the mother water containing higher amount of these admixtures. The latter presents cesium iodide solution with the concentration of Csl ca. 4042 wt. $\%$.

If such solution is subjected to cooling the process goes along the line 'LTMC' in Fig. 3. The analysis of this process shows that the cooling to WSE temperature results in the crystallization of Csl, approximately $230 \mathrm{~g}$ per $1 \mathrm{~kg}$ of the mother water and the following cooling causes the crystallization of WSE. So after the performing this process to complete precipitation $52 \%$ of Csl is deposited from the solution as pure crystals, $48 \%$ of Csl are crystallized together with water as WSE. Therefore, LTMC presents itself a combination of MC with slow rate of the solution cooling $\left(1^{\circ} \mathrm{C} / \mathrm{h}\right)$ and LTDC. Usually LTMC stage is 
Table 3. The main technological features of crystallization methods of Csl purification

\begin{tabular}{|c|c|c|c||}
\hline Parameter & MC & LTDC/ws & LTMC \\
\hline Average rate of solution cooling, C/h & ${ }^{\circ} 6-10$ & 1 & 1 \\
Working temperature range length, ${ }^{\circ} \mathrm{C}$ & $65-70$ & $25-30$ & $25-30$ \\
Loss of the main substance per stage, $\%$ & 40 & $3-4$ & $3-4$ \\
$\beta_{\mathrm{Na}}$ & 0.07 & 0.90 & 0.47 \\
$\beta_{\mathrm{K}}$ & 0.15 & 0.88 & 0.60 \\
$\beta_{\mathrm{Rb}}$ & 0.21 & 0.87 & 0.61 \\
$\beta_{\mathrm{Tl}}$ & 1.48 & - & 1.06 \\
$\begin{array}{c}\text { Number of stages which efficiency corresponds to } \\
1 \text { stage of MC/loss of the main product (Csl), \% }\end{array}$ & $1 / 40$ & $10-11 / 30-44$ & $3-4 / 9-16$ \\
\hline
\end{tabular}

finished after the solidification of $c a .97 \%$ of the cooled solution.

As for the quantitative characteristics of LTMC regarding isomorphic admixtures, they can be derived from Fig. 4 .

As is seen, the trends observed for $\mathrm{MC}$ and LTDC maintain during the LTMC, there is sequential removal of alkali metals admixtures, whereas $\mathrm{Tl}$ concentration in the product increases. The rate of removal of admixtures is dependent on the concentration of main admixtures: sodium and sulfate ions, and when their concentration reduces to $0.05-0.1$ wt. $\%$ the rate of the admixture removal essentially increases [2]. Using Eq. (5) we estimated the slopes of sequences $1,2,3$ and 4 . The slope of plot 1 is $0.333 \pm 0.01$ that corresponds to $\beta=0.465$, for plot 2 the slope is $0.217 \pm 0.02$ and $\beta=$ 0.61 and for plot 2 the slope is $0.24 \pm 0.03$ and $\beta=0.58$. Two latter slopes are practically the same (within experimental error). In contrast with the alkaline metal admixtures for $\mathrm{Tl}$ one the slope is negative ($0.026 \pm 0.004$ ) and $\beta=1.06$, i.e., thallium admixture is sequentially accumulated in the product (Csl) during multiply LTMC. As is seen, there is no increase of $\beta$ with the reduction of admixture concentration. It means that because of low overcooling the amount of defects in the crystallized product is considerably lower that, e.g., in the case of MC and the use of LTMC for the purification of extra pure salt or solutions seems to be more effective.

Finishing this comparison of crystallization methods of Csl purification let us tabulate their main advantages and disadvantages (Table 3).

So, MC and LTMC/ws methods are comparable by their efficiency, but, the latter method is considerably slower. The use of

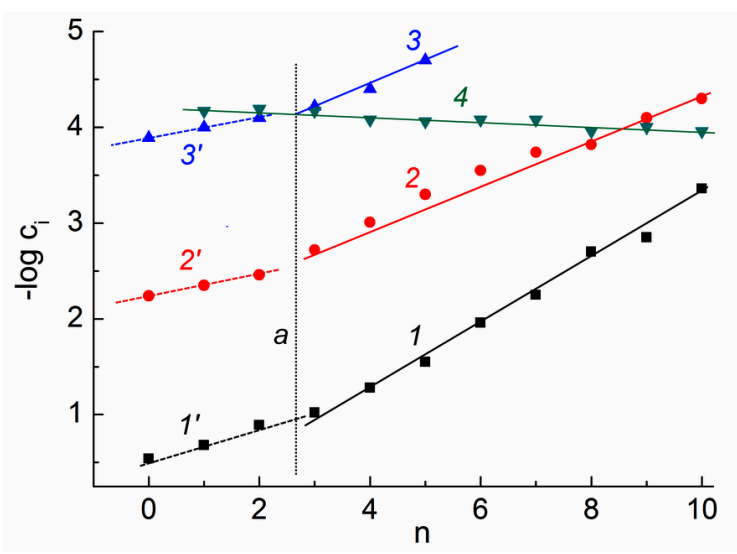

Fig. 4. The dependence of $-\log c_{i}$ (mas.\%) from a number of stages of LTMC without stirring at freezing chamber temperature was $-14--16^{\circ} \mathrm{C}$ for admixtures of $\mathrm{Na}\left(1,1^{\prime}, i=\right.$ $\mathrm{Na}), \mathrm{K}\left(2,2^{\prime}, i=\mathrm{K}\right), \mathrm{Rb}\left(3,3^{\prime}, i=\mathrm{Rb}\right)$ and $\mathrm{TI}$ $(4, i=\mathrm{TI})$, line "a" denotes a threshold where the rate of the admixture removal changes.

the LTMC method gives the possibility to obtain the product (Csl) of the 'extra pure' quality comparable with that obtained by MC, however, the yield of the product is considerably higher (3-fold MC allows obtaining 22-25\% of product whereas 12fold LTMC gives 55-60\%).

From the above-said it follows that the thermal conditions of LTMC are closer to the equilibrium ones than in the case of $\mathrm{MC}$ (smaller overcooling) that gives the possibility to obtain Csl of enhanced quality using LTMC.

\section{Conclusions}

The presented above comparison of the methods of aqueous solutions of Csl purification by mass crystallization with natural cooling (MC), low-temperature directed crystallization without stirring (LTDC/ws) 
and low-temperature mixed crystallization (LTMC) leads to the following conclusions.

The MC routine applied in industrial conditions has the highest cooling rate (6$\left.10^{\circ} \mathrm{C} / \mathrm{h}\right)$. The effective purification coefficients $(\beta)$ for the the isomorphic admixtures are too small: 0.07 for $\mathrm{Na}$ and $c a .0 .6$ for $\mathrm{K}$ and $\mathrm{Rb}$ that provides their effective removal. An obvious disadvantage of $\mathrm{MC}$ is in the relatively low yield per stage $(60 \%)$.

The low-temperature methods LTDC and LTMC are characterized by the relatively small cooling rate $\left(\sim 1^{\circ} \mathrm{C} / \mathrm{h}\right)$ and higher yields of the purified product per stage (95-97\%). However, $\beta$ values are closer to 1 than those for MC, for LTMC they are 0.465 for $\mathrm{Na}$ and $c a$. 0.6 for $\mathrm{K}$ and $\mathrm{Rb}$ and for LTDC/ws values of $\beta$ for alkali metals approaches 0.9 . With respect to the efficiency of the purification 1 stage of $\mathrm{MC}$ is equivalent to 3-4 stages of LTMC or 1011 stages of LTDC/ws and the yield of the product is ca. $60 \%, 85-90 \%$ and 55$70 \%$, respectively.

All the mentioned crystallization methods do not provide removal of $\mathrm{Tl}$ which is accumulated in the product, $\beta$ value is varied from 1.06 for LTMC to ca. 1.48 for MC.
The analysis shows that the LTMC method can be the most promising for the obtaining of extra pure Csl of better quality due to low enough values of $\beta$ for $\mathrm{Na}, \mathrm{K}$ and $\mathrm{Rb}(\beta=0.46 \div 0.6)$ and considerably smaller than in the case of $\mathrm{MC}$ rate of cooling $\left(1^{\circ} \mathrm{C} / \mathrm{h}\right.$ vs. $\left.10^{\circ} \mathrm{C} / \mathrm{h}\right)$.

Acknowledgement. The support of $\mathrm{Na}$ tional Academy of Sciences (Program "New functional substances and materials of chemical production", project No. 4-18 from 01.03.2018) is gratefully acknowledged.

\section{References}

1. Properties of Inorganic Compounds, Handbook, ed. by A.I.Efimov et al., Khimiya, Leningrad (1983) [in Russian].

2. A.Yu.Boyarintsev, V.L.Cherginets, T.V.Ponomarenko et al., Functional Materials, 24, 640 (2017).

3. V.S.Urusov, I.F.Kravchuk, Geokhimiya, No.7, 963 (1978).

4. A.B.Blank, Analysis of Pure Compounds with the Use of Crystallization Concentrating, Khimiya, Moscow (1986) [in Russian].

5. L.P.Eksperiandova, Non-traditional Methods in Analysis of Functional Materials and Objects of Environment, ISMA, Kharkov (2011) [in Russian]. 